\title{
High efficiency removal of As(III) from waters using a new and friendly adsorbent based on sugarcane bagasse and corncob husk Fe-coated biochars
}

\author{
José Ignácio Z. Montero ${ }^{\mathrm{a}}$, Adnívia S.C. Monteiro ${ }^{\mathrm{a}, \mathrm{b}}$, Erik S.J. Gontijo ${ }^{\mathrm{a}, \mathrm{c}}$, Carolina C. Bueno ${ }^{\mathrm{a}}$, \\ Minéia A. de Moraes ${ }^{a}$, André H. Rosa ${ }^{a, *}$ \\ a Sao Paulo State University (UNESP), Institute of Science and Technology, Av. Tres de Marco, 511, Alto da Boa Vista, CEP: 18087-180, Sorocaba, SP, Brazil \\ ${ }^{\mathrm{b}}$ Federal University of Sergipe (UFS), Postgraduate Program in Water Resources, Av. Marechal Rondon, s/n - Jd. Rosa Elze, 49100-000, Sao Cristovao, SE, Brazil \\ ${ }^{\mathrm{c}}$ UFZ-Helmholtz Centre for Environmental Research, Department Lake Research, Brueckstr 3a, 39114 Magdeburg, Germany
}

\section{A R T I C L E IN F O}

Keywords:

Arsenic

Modified biochars

Adsorption

Water treatment

Kinetics parameters

\begin{abstract}
A B S T R A C T
Water contamination of As is a big issue in many areas around the globe. Therefore, cheap and efficient techniques are essential facing traditional treatment methods. Then, biochars (BC) emerged recently as material that can be used for As removal. However, research about efficiency of BC produced from local feedstock is still needed. The purpose of this study is to assess the efficiency of BC produced from sugarcane bagasse (SB) together with corncob husk $(\mathrm{CH})$ with and without $\mathrm{Fe}(\mathrm{III})\left(\mathrm{BC}_{\mathrm{Fe}}\right)$ modification to be used for removal of As(III) from waters. The $\mathrm{BC}$ and $\mathrm{BC}_{\mathrm{Fe}}$ produced at different pyrolysis temperatures were characterised using FTIR and SEM/ EDS. Adsorption capacities of $\mathrm{BC}$ and $\mathrm{BC}_{\mathrm{Fe}}$ were evaluated via batch adsorption, desorption and column tests and their performance was compared with adsorption using activated carbon. The results showed that Fe modification improve substantially the As(III) adsorption in a way that both $\mathrm{BC}_{\mathrm{Fe}-\mathrm{SB}}$ and $\mathrm{BC}_{\mathrm{Fe}-\mathrm{CH}}$ removed from $85 \%$ to $99.9 \%$ from $1000 \mu \mathrm{g} / \mathrm{L} \mathrm{As}(\mathrm{III})$ solutions. Both materials fitted well in Langmuir model and the maximum adsorption capacity was $20 \mathrm{mg} / \mathrm{g}$ for $\mathrm{BC}_{\mathrm{Fe}-\mathrm{SB}}$ and $50 \mathrm{mg} / \mathrm{g}$ for $\mathrm{BC}_{\mathrm{Fe}-\mathrm{CH}}$. The adsorption kinetics of $\mathrm{BC}_{\mathrm{Fe}}$ was fast ( $\leq 30 \mathrm{~min}$ ) and it had a better performance than activated carbon. The column tests showed that the process is efficient even at high As(III) concentrations. The fast removal process and good removal results make the $\mathrm{BC}_{\mathrm{Fe}-\mathrm{SB}}$ and $\mathrm{BC}_{\mathrm{Fe}-\mathrm{CH}}$ attractive for in situ and commercial (filters) use, since time and efficiency are required in new technologies.
\end{abstract}

\section{Introduction}

Arsenic (As) contamination of aquatic systems is a worldwide problem that severely affects people and animals. The concern related to As comes from its prevalence and high toxicity, which depends on its chemical form (Jain and Ali, 2000). Generally, As(III) species are the most toxic followed by As(V) and organic species (Jain and Ali, 2000; Wang and Mulligan, 2006).

Weathering of rocks, leaching of soils and volcanic emissions are the main natural sources of As in aquatic systems (Smedley and Kinniburgh, 2002). Human activities like mining, smelting, fossil fuel combustion, waste disposal and use of some pesticides and herbicides also contribute to the input of this metalloid in the environment (Azizur Rahman and Hasegawa, 2012; Morin and Calas, 2006). The increasing amount of As released via anthropogenic sources boosts the world problems related to As chronic exposure, which can cause skin diseases and cancer (Sharma and Sohn, 2009). In this way, a cheap and efficient method to remove
As from contaminated water and effluents is highly desirable.

Currently, the best known techniques for the removal of As and other contaminants from aquatic systems include processes such as (ad) sorption and ion-exchange using activated carbon/modified activated carbon and alumina, iron coated sand, ion-exchange resins (Asfaram et al., 2015; Bazrafshan et al., 2017; Cumbal et al., 2003; Dambies, 2005; Haron, 1997), biosorbents (chitin, chitosan, cellulose sponge (Guo and Chen, 2005; Muñoz et al., 2002), biomass (Ghimire et al., 2002; J. Kim et al., 2006; Pokhrel and Viraraghavan, 2006)) and nanoadsorbent (Asfaram et al., 2017a, 2018; Lata and Samadder, 2016; Qu et al., 2013), such as nanocrystalline magnetite (Mayo et al., 2007), graphene oxide (Chandra et al., 2010) and $\mathrm{Mn}_{0.4} \mathrm{Zn}_{0.6} \mathrm{Fe}_{2} \mathrm{O}_{4}$ nanoparticles (Asfaram et al., 2018). Some of other techniques used are coagulation, electrocoagulation (Nidheesh and Singh, 2017; Ratna Kumar et al., 2004; Thakur and Mondal, 2017), coprecipitation, phytoremediation (Leão et al., 2017; Natarajan et al., 2011), bioremediation (Gihring et al., 2001) and biofilters (Sharma and Sohn, 2009;

\footnotetext{
* Corresponding author.

E-mail address: ahrosa@sorocaba.unesp.br (A.H. Rosa).
} 
Vithanage et al., 2017), solvent extraction (Budinova et al., 2006), foam flotation (Kordmostafapour et al., 2006; Pacheco and Torem, 2002) and also membrane techniques, such as nanofiltration, reverse osmosis, and electrodialysis (Ballinas et al., 2004; Choong et al., 2007; D.H. Kim et al., 2006; Ungureanu et al., 2015).

Despite the good adsorption removal efficiency, materials used in most of these techniques are expensive and require a large amount of energy. Hence, easily available (available locally), cost-effective (processing required and treatment conditions) and efficient materials are required. The use of biochar (BC) as an adsorbent to remove As from water is classified as a low-cost adsorbent technique, making BC usage particularly advantageous when compared to the techniques described previously (Asfaram et al., 2017b). Other low-cost adsorbents can be obtained from industrial by-products/wastes chars and coals (Mohan and Chander, 2006), red mud (Genç et al., 2003; Soner Altundoğan et al., 2000), blast furnace slag (Ahn et al., 2003; Zhang and Itoh, 2005), fly ash (Diamadopoulos et al., 1993; Gupta et al., 2005), zeolites (Wang and Peng, 2010), clay minerals, coconut shells, wood char, lignin, petroleum coke, bone-char, peat, sawdust, carbon black, rice hulls, sugar, peach pits (Pollard et al., 1992) and sand (Ramakrishna et al., 2006). Besides the economic factor, agricultural products and byproducts are preferable because the storage and handling of these types of wastes are easy and safe and they do not need specific operation and maintenance, and provide a noble destination for the organic load produced that could lead to accumulation of nutrients in the environment.

Surface area may not be a primary factor for adsorption on BC and, thus high surface area does not necessarily mean high adsorption capacity. Therefore, the adsorption of As probably depends on the surface chemistry (Corapcioglu and Huang, 1987). Hence, it is known that ligands as As oxyanions are adsorbed on iron hydroxide and aluminium sulphate flocs as Fe complexes (Hering, 1996). This given mechanism can be transferred to the adsorbent materials by chemical modification and thus improve the removal capacity of this type of contaminants. Consequently, the chemical modification of BC transforms it into an adsorbent with positive charge, which facilitates the As removal by the means of Coulombic interactions. Additionally, the presence of $\mathrm{Fe}$ groups in BC may impart a magnetic feature to the adsorbent that facilitates removal of contaminated water system (Dong et al., 2018).

This study aims to evaluate the capabilities of biochar and Fe-coated biochar produced from corncob husk $(\mathrm{CH})$ and sugarcane bagasse (SB) of Brazilian crops to remove As(III) from highly contaminated aquatic systems. These feedstocks can be readily available, particularly in countries like Brazil and China, which have big sugarcane and/or maize crops (Bueno et al., 2017; Moraes et al., 2012). In addition, the use of leftover biomass from maize (corncob husk) and sugarcane (bagasse) production would minimise the waste generation and impact of these crops on the environment (Manochio et al., 2017). The As removal efficiency of Fe-coated biochars were also compared with commercially activated carbon. Furthermore, the efficiency of As removal by Fecoated biochar in a column leaching experiment was tested.

\section{Experimental}

\subsection{Biochar and Fe-coated biochar preparation}

The corncob husk (CH) and sugarcane bagasse (SB) were washed with water and dried in a drying oven with mechanical air circulation at $80{ }^{\circ} \mathrm{C}$ for $48 \mathrm{~h}$. The material was crushed (Willey mill MA048) and the biomass powder $(60 \mathrm{~g})$ was pyrolyzed using a bed cylindrical reactor $\left(0.82 \mathrm{~cm}^{3}\right)$ in a muffle furnace (EDGCON-3P). Four different biochars (BC) were produced after setting the pyrolysis temperature at 300, 400, 500 and $600{ }^{\circ} \mathrm{C}$ with an increase rate of $10{ }^{\circ} \mathrm{C} / \mathrm{min}$. The furnace was kept in the target temperature for $180 \mathrm{~min}$ (retention time) and it was cooled at room temperature for $12 \mathrm{~h}$ (overnight).

Fe-coated biochars $\left(\mathrm{BC}_{\mathrm{Fe}}\right)$ were produced by immersing the biomass in a $\mathrm{FeCl}_{3}$ solution $(2.5 \mathrm{~mol} / \mathrm{L})$ for $2 \mathrm{~h}$. The mixture was then dried at $80^{\circ} \mathrm{C}$ for $2 \mathrm{~h}$ in a drying oven with mechanical air circulation. The biomass modified with $\mathrm{Fe}$ was pyrolyzed in porcelain crucibles using the same treatments ( 4 different temperatures) and conditions used for unmodified BC.

All $\mathrm{BC}$ and $\mathrm{BC}_{\mathrm{Fe}}$ were passed through a 35-mesh sieve and stored in polypropylene bottles at room temperature until analysis.

\subsection{Characterisation of biochar and Fe-coated biochar}

To investigate the evolution of porosity and changes in elemental composition, the surfaces of the biochars and Fe-coated biochars were analysed by a scanning electron microscope (SEM) and by energy dispersive X-ray spectroscopy (EDS) (JEOL JSM-6010LA).

A Fourier transform infrared (FTIR) spectrometer (PerkinElmer Spectrum 65 FTIR) with attenuated total reflection (ATR) was used to study the surface functional groups of all biochars. All spectra were obtained with $4 \mathrm{~cm}^{-1}$ resolution over spectral range from 4000 to $650 \mathrm{~cm}^{-1}$ (32 scans).

\section{3. $p H$ of zero point of charge $\left(\mathrm{pH}_{z p c}\right)$}

The $\mathrm{pH}$ of zero point of charge $\left(\mathrm{pH}_{\mathrm{zpc}}\right)$ was determined from adding $0.5 \mathrm{mg}$ of biochar in $50 \mathrm{~mL}$ of ultrapure water. The experiments were performed with $\mathrm{BC}$ and $\mathrm{BC}_{\mathrm{Fe}}$ from $\mathrm{SB}$ and $\mathrm{CH}$ (4 sets of experiments). The $\mathrm{pH}$ was adjusted in the range $2-12$ (11 samples) using $\mathrm{NaOH}$ $0.10 \mathrm{~mol} / \mathrm{L}$ and $\mathrm{HCl} 0.10 \mathrm{~mol} / \mathrm{L}$ solutions for each biomass. All samples were shaken at $3 \mathrm{~g}$ at $25^{\circ} \mathrm{C}$ for $24 \mathrm{~h}$. Measuring the $\mathrm{pH}$ of each sample and analysing the data $(\Delta \mathrm{pH} \times$ initial $\mathrm{pH})$ it was found that the initial $\mathrm{pH}$ and the final $\mathrm{pH}$ were the same, which corresponds to the $\mathrm{pH}_{\mathrm{zpc}}$ (Mohan et al., 2014).

\subsection{Adsorption kinetics and isotherms}

Adsorption kinetics experiments of $\mathrm{As}(\mathrm{III})$ on $\mathrm{BC}$ and $\mathrm{BC}_{\mathrm{Fe}}$ produced at all pyrolysis temperatures $\left(300,400,500\right.$ and $600{ }^{\circ} \mathrm{C}$ ) from $\mathrm{SB}$ and $\mathrm{CH}$ biomass were carried out by mixing $0.1 \mathrm{~g}$ of the adsorbent with $100 \mathrm{~mL}$ of $1000 \mu \mathrm{g} / \mathrm{L}$ As(III) solution in $125 \mathrm{~mL}$ erlenmeyers. The same procedure was carried out for commercially activated carbon for comparison. The erlenmeyers were shaken in a shaker for $24 \mathrm{~h}$ at $3 \mathrm{~g}$ at room temperature. Experiments were also performed without adsorbents to evaluate a possible precipitation of As. Visual MINTEQ software (freeware, version 3.0) was used to evaluate possible precipitation of As in the experiments under the same conditions. Aliquots $(2 \mathrm{~mL})$ were taken after $0,1,10,20,30,45,60,90,180,300,600$ and 1440 min using syringes and immediately filtered through $0.45 \mu \mathrm{m}$ pore size PVDF filters. All experiments were performed in duplicate at three different $\mathrm{pH}(4,5$ and 6$)$. The As in the filtered samples were determined by inductively coupled plasma-atomic emission spectrometry (ICP OES, Agilent Technologies 700 Series).

The kinetic study provides important information regarding the reaction pathways and the mechanisms of sorption. The reaction rate and the adsorption mechanisms, for instance, play an essential role in water treatment process, since they determine the contact time necessary to the complete and efficient adsorption of the adsorbate on the adsorbent (Ho and McKay, 1999). Therefore, the pseudo-first order kinetic model and the pseudo-second order model were determined in order to investigate the sorption mechanisms of As(III) onto BC and $\mathrm{BC}_{\mathrm{Fe}}$. The equation used to describe the pseudo-first order kinetic model is (Eq. (1)) (Van Vinh et al., 2015):

$\log \left(q_{e}-q_{t}\right)=\log q_{e}-\left(k_{1} / 2.303\right) t$,

where $\mathrm{k}_{1}(\mathrm{mg} / \mathrm{g} \cdot \mathrm{min})$ is pseudo-first order adsorption rate constant (from slopes of linear plot $\log \left(\mathrm{q}_{\mathrm{e}}-\mathrm{q}_{\mathrm{t}}\right) \times \mathrm{t}$ ), $\mathrm{q}_{\mathrm{e}}$ is the amount of adsorbate at the equilibrium time, $q_{t}$ is the amount of adsorbent at equilibrium time and $\mathrm{t}$ is the time. 
The pseudo-second order model can be expressed by the equation (Eq. (2)) (Van Vinh et al., 2015):

$t / q_{t}=1 /\left(k_{2} q_{e}^{2}\right)+\left(1 / q_{e}\right) t$,

where $\mathrm{k}_{2}$ (mg/g.min) is the pseudo-second-order adsorption rate constant.

The amount of metals adsorbed (q, mg of metal/ $\mathrm{g}$ of adsorbent) on all $\mathrm{BC}_{\mathrm{Fe}}\left(300^{\circ} \mathrm{C}\right)$ was assessed based on $\mathrm{pH}$, contact time, concentration of adsorbent and adsorbate. The following equation (Eq. (3)) was used to calculate q (Mohan et al., 2007):

$q=\left(C_{0}-C_{e}\right) V / W$,

where $\mathrm{C}_{0}$ and $\mathrm{C}_{\mathrm{e}}$ are respectively the initial and equilibrium metal ion concentrations in solution $(\mathrm{mg} / \mathrm{L}), \mathrm{V}$ is the adsorbate volume and $\mathrm{W}$ is the adsorbent weight $(\mathrm{g})$.

Adsorption isotherms of $\mathrm{As}(\mathrm{III})$ to $\mathrm{BC}$ were determined by mixing $0.1 \mathrm{~g}$ of $\mathrm{BC}_{\mathrm{Fe}}$ at $300^{\circ} \mathrm{C}$ in $100 \mathrm{~mL}$ of $\mathrm{As}(\mathrm{III})$ solutions of concentration ranging from 1 to $50 \mathrm{mg} / \mathrm{L}$. The $\mathrm{pH}$ values of all treatments were adjusted to 4 and the samples were shaken in a shaker for $360 \mathrm{~min}$ at $3 \mathrm{~g}$ and $25{ }^{\circ} \mathrm{C}$. The experiment duration time was set to $360 \mathrm{~min}$ to assure that the adsorption equilibrium was established based on kinetic experiments results. Aliquots of the samples $(2 \mathrm{~mL})$ were taken and filtered through $0.45 \mu \mathrm{m}$ pore size PVDF filters. All experiments were performed in duplicate.

The performance and isotherm parameters of $\mathrm{BC}_{\mathrm{Fe}-\mathrm{CH}}$ and $\mathrm{BC}_{\mathrm{Fe}-\mathrm{SB}}$ produced at $300{ }^{\circ} \mathrm{C}$ were evaluated based on the nonlinear Langmuir and Freundlich models. The Langmuir isotherm model explains the adsorption processes in a homogeneous media, where all adsorption sites of the adsorbent have equal affinity to the adsorbate. This model is valid for a monolayer sorption mechanism and none of the binding sites of adsorbent affects its neighbours (Baig et al., 2014; Mohan et al., 2007). The equation (Eq. (4)) used to describe this nonlinear model is (Mohan et al., 2007):

$q_{e}=Q^{0} b C_{e} /\left(1+b C_{e}\right)$,

where $\mathrm{q}_{\mathrm{e}}$ is the amount of solute adsorbed $(\mu \mathrm{g} / \mathrm{g}) ; \mathrm{Q}^{0}$ is the monolayer adsorption capacity $(\mu \mathrm{g} / \mathrm{g})$; Ce is the equilibrium concentration of solute bulk solution $(\mathrm{mg} / \mathrm{L})$ and $\mathrm{b}$ is the constant linked to free energy.

In contrast to the Langmuir model, the nonlinear Freundlich model describes the adsorption processes in a heterogeneous media. Furthermore, this model is not valid for a monolayer sorption mechanism and it can only be applied from low to intermediate concentration levels (Mohan et al., 2007). The formula (Eq. (5)) used to describe this model is:

$q_{e}=K_{F} C_{e}^{\frac{1}{n}}$

where $\mathrm{K}_{\mathrm{F}}$ is the relative adsorption capacity constant of the adsorbent $(\mathrm{L} / \mu \mathrm{g})$ and $1 / \mathrm{n}$ is the adsorption constant intensity.

\subsection{Biochar mass influence on As(III) adsorption}

The experiments performed with $\mathrm{BC}_{\mathrm{Fe}}$ produced at $300^{\circ} \mathrm{C}$ both from $\mathrm{CH}$ and $\mathrm{SB}$ biomass to evaluate the influence of the mass of $\mathrm{BC}_{\mathrm{Fe}}$ on removal of As(III). Five different amounts of $\mathrm{BC}_{\mathrm{Fe}}(0.05,0.1,0.2,0.4$ and $0.5 \mathrm{~g}$ ) were added to flasks with $100 \mathrm{~mL}$ solution of $1000 \mu \mathrm{g} / \mathrm{L} \mathrm{As}$ (III). The $\mathrm{pH}$ values of all experiments were adjusted to 4 and the flasks were shaken in a shaker at $3 \mathrm{~g}$ at room temperature. Aliquots were taken at $0,1,10,20,30,45,60,90,180,300$ and $360 \mathrm{~min}$ and afterwards they were filtered through $0.45 \mu \mathrm{m}$ membranes. As concentration was determined in an ICP-OES as described in Section 2.4.

\subsection{Desorption and re-adsorption experiments}

Batch desorption experiments were performed to verify if the adsorption of As(III) on biochars is reversible. This study consists of an adsorption followed by a desorption phase using the best conditions from previous tests (Sections 2.3-2.5). Briefly, $0.1 \mathrm{~g}$ of Fe-coated biochar $\left(\mathrm{BC}_{\mathrm{Fe}-\mathrm{SB}}\right.$ and $\mathrm{BC}_{\mathrm{Fe}-\mathrm{CH}}$ produced at $\left.300^{\circ} \mathrm{C}\right)$ was added to $100 \mathrm{~mL}$ solution ( $\mathrm{pH} 4$ ) containing $1000 \mu \mathrm{g} / \mathrm{L} \mathrm{As}(\mathrm{III})$. The mixture was shaken at $3 \mathrm{~g}$ for $300 \mathrm{~min}$ (adsorption phase). Extra adsorption experiments were performed to further investigate the interactions between As(III) and $\mathrm{BC}_{\mathrm{Fe}}$ after adsorption. FTIR spectra of $\mathrm{BC}_{\mathrm{Fe}}$ before and after $\mathrm{As}(\mathrm{III})$ adsorption were acquired (as Section 2.2) and afterwards compared.

After the sorption step, the supernatant was substituted by $100 \mathrm{~mL}$ solution containing $0.01 \mathrm{~mol} / \mathrm{L} \mathrm{CaCl}_{2}$, as described by Huang et al. (1998) and Zhang et al. (2010). The suspensions were shaken at $3 \mathrm{~g}$ and aliquots were taken after $300 \mathrm{~min}$ (desorption phase). Afterwards, the samples were filtered through $0.45 \mu \mathrm{m}$ membranes and the desorbed metalloid in the samples were measured using an ICP-OES. The desorption experiments with $\mathrm{BC}_{\mathrm{Fe}-\mathrm{SB}}$ and $\mathrm{BC}_{\mathrm{Fe}-\mathrm{CH}}$ were performed in triplicate.

After the desorption, a re-adsorption experiment of the $\mathrm{BC}_{\mathrm{Fe}-\mathrm{SB}}$ and $\mathrm{BC}_{\mathrm{Fe}-\mathrm{CH}}$ were performed using the same conditions of the first adsorption. The samples were filtered through $0.45 \mu \mathrm{m}$ membranes and the desorbed metalloid in the samples were measured using an ICP-OES as described previously.

\subsection{Influence of ionic strength on As adsorption}

The influence of the ionic strength on As(III) adsorption was evaluated using the $\mathrm{BC}$ with the best removal rates and the best conditions as described in Section 2.6. Briefly, $0.1 \mathrm{~g}$ of $\mathrm{BC}\left(\mathrm{BC}_{\mathrm{Fe}-\mathrm{SB}}\right.$ and $\left.\mathrm{BC}_{\mathrm{Fe}-\mathrm{CH}}\right)$ was added to $100 \mathrm{~mL}$ solution (pH 4) containing $1000 \mu \mathrm{g} / \mathrm{L} \mathrm{As(III).} \mathrm{The}$ experiments were performed in three different $\mathrm{NaNO}_{3}$ concentrations: 0.01, 0.1 and $1 \mathrm{~mol} / \mathrm{L}$. The mixtures were shaken at $25^{\circ} \mathrm{C}(3 \mathrm{~g})$ and aliquots were taken at $0,1,10,20,30,45,60,90,180$ and $300 \mathrm{~min}$. The samples were filtered through $0.45 \mu \mathrm{m}$ membranes and analysed in ICPOES.

\subsection{Column leaching experiment}

A glass column (24 mm diameter) was packed with $5 \mathrm{~g}$ of $\mathrm{BC}_{\mathrm{Fe}}$ produced from $\mathrm{SB}$ and $\mathrm{CH}$ at $300^{\circ} \mathrm{C}$. The packed column was previously conditioned with $200 \mathrm{~mL}$ of $\mathrm{HNO}_{3} 0.1 \mathrm{~mol} / \mathrm{L}$. As(III) solution $(50 \mathrm{mg} / \mathrm{L})$ was supplied at a rate of about $3.5 \mathrm{~mL} / \mathrm{min}$. The total volume passed through the system was approximately $1300 \mathrm{~mL}$ and aliquots of the solution were collected at $0,1,10,20,30,45,60,90,180,300$ and $360 \mathrm{~min}$. As concentration was determined in an ICP-OES.

\section{Results and discussion}

\subsection{Biochars characterisation}

The yield of all BC produced from CH and SB was similar (Table A.1, Supplementary Material). On the other hand, the modified biochars $\left(\mathrm{BC}_{\mathrm{Fe}}\right)$ produced at 300 and $400{ }^{\circ} \mathrm{C}$ had smaller yield when they are compared with unmodified biochars. Both biochars $\mathrm{BC}$ and $\mathrm{BC}_{\mathrm{Fe}}$ had similar yield when produced at 500 and $600{ }^{\circ} \mathrm{C}$.

The smallest yield of biochars with the increase of temperature is related to the volatilisation of organic matter, which leads to an increase in the amount of fixed $\mathrm{C}$ and decrease in the amount of $\mathrm{H}, \mathrm{O}$ (Domingues et al., 2014).

The average of $\mathrm{pH}_{\mathrm{zpc}}$ found in $\mathrm{BC}$ and $\mathrm{BC}_{\mathrm{Fe}}$ produced from $\mathrm{CH}$ and SB at all pyrolysis temperatures (300, 400, 500 and $\left.600{ }^{\circ} \mathrm{C}\right)$ was 6.05 . The results indicate that the surface of these biochars was positively charged (protonated sites) at $\mathrm{pH}$ lower than 6.05 and negatively charged at values higher than 6.05. Since As(III) appears mainly as oxyanions in higher $\mathrm{pH}(>9.2)$ and the negative surface of biochars prioritizes its adsorption, the $\mathrm{pH} 4,5$ and 6 were chosen to perform all experiments (Sharma and Sohn, 2009; Vithanage et al., 2017).

The SEM pictures of the $\mathrm{BC}_{\mathrm{SB}}$ and $\mathrm{BC}_{\mathrm{CH}}$ produced at $300{ }^{\circ} \mathrm{C}$ 

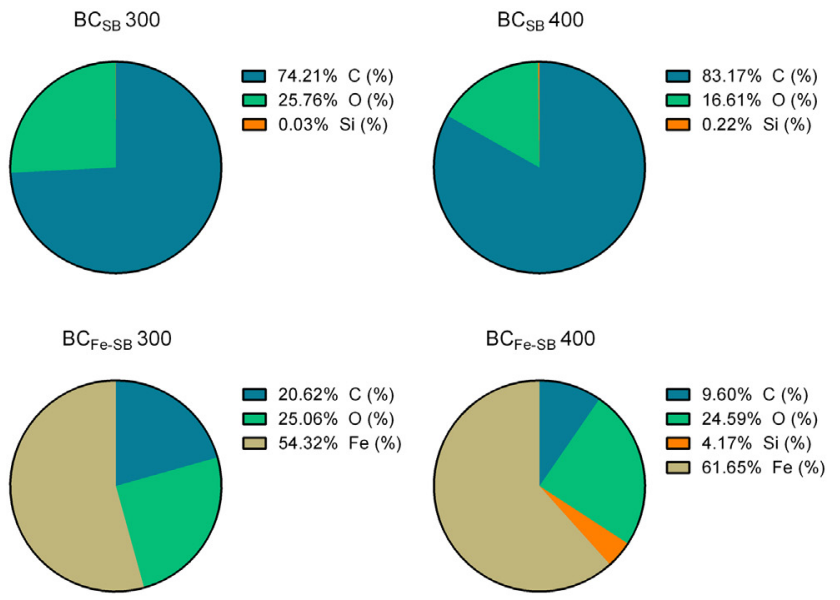

$\mathrm{BC}_{\mathrm{CH}} 300$
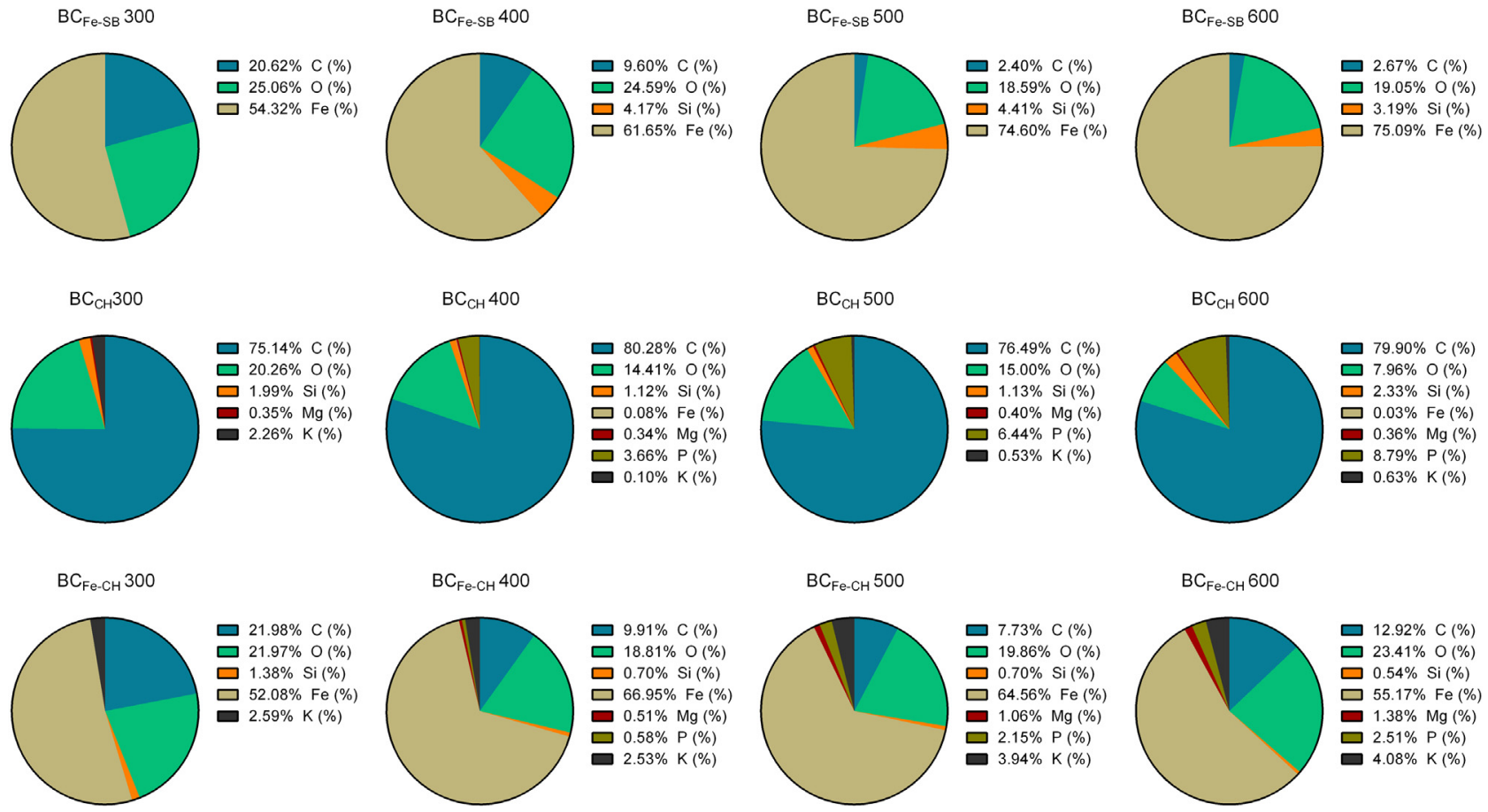

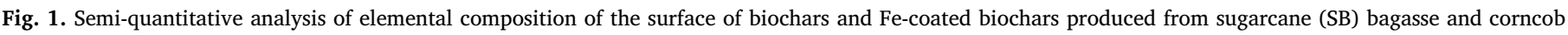

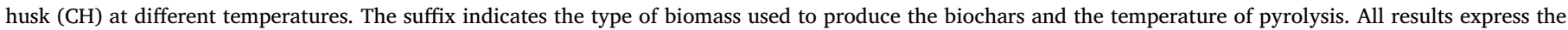
mass percent composition of the elements.

displayed no morphological differences when compared to the samples produced at 400,500 and $600^{\circ} \mathrm{C}$. However, while the $\mathrm{BC}_{\mathrm{SB}}$ sample had more definite pores, the $\mathrm{BC}_{\mathrm{CH}}$ samples had no defined porous structure (see Appendix A, Fig. A.1). Therefore, this indicates that the chosen biomass played an important role in the evolution of the morphological characteristics during pyrolysis treatment.

The SEM images of the Fe-modified biochars $\left(\mathrm{BC}_{\mathrm{Fe}}\right)$ show that the pores observed on the $\mathrm{BC}_{\mathrm{SB}}$ were impregnated with Fe (Appendix A, Fig. A.2). Consequently, a new type of material was formed and it can be characterised as a colloidal composite (Zhang et al., 2013). The same morphological trend was observed to higher pyrolysis temperatures (500 and $600{ }^{\circ} \mathrm{C}$ ), as shown in Fig. A. 2 in Supplementary Section. Apparently, the micropores were covered with microcrystals of $\mathrm{FeCl}_{3}$.

The EDS analyses of $\mathrm{BC}$ and $\mathrm{BC}_{\mathrm{Fe}}$ from sugarcane bagasse indicate that the elemental composition (semi-quantitative) of the surface of the samples was deeply modified after biomass treatment (Fig. 1). This modification can change the properties of adsorption of the biochars produced, since new functional groups increase the amount of $\mathrm{O}$ and $\mathrm{Fe}$ on the surface of the Fe-coated biochar after treatment with $\mathrm{FeCl}_{3}$. The $\mathrm{BC}$ produced at 400,500 and $600{ }^{\circ} \mathrm{C}$ are similar to the elemental surface composition. In the $\mathrm{BC}_{\mathrm{Fe}}$ samples, Fe covered most of the surface, since the amount of $\mathrm{C}$ decreased in relation to Fe. However, no significant amount of $\mathrm{Si}$ in the sample $\mathrm{BC}_{\mathrm{Fe}-\mathrm{SB}}$ was observed at $300{ }^{\circ} \mathrm{C}$.

The same trend of surface modification of $\mathrm{BC}_{\mathrm{Fe}-\mathrm{SB}}$ was observed in $\mathrm{BC}_{\mathrm{Fe}-\mathrm{CH}}$ (Fig. 1). However, some extra elemental modifications were detected in the $\mathrm{BC}_{\mathrm{CH}}$ and $\mathrm{BC}_{\mathrm{Fe}-\mathrm{CH}}$ since $\mathrm{K}, \mathrm{Mg}$ and $\mathrm{P}$ appeared in external composition depending on the pyrolysis temperature.
The FTIR results reveal that all samples are similar and only small differences related to the type of biomass and treatment with Fe were observed (Fig. A.8, Supplementary Section). The band that appeared around $3100-3400 \mathrm{~cm}^{-1}$ is associated to the stretching mode of $-\mathrm{OH}$ and it was present especially in the $\mathrm{BC}_{\mathrm{CH}}$ and $\mathrm{BC}_{\mathrm{Fe}-\mathrm{SB}}$. The discrete peaks around $1614-1630 \mathrm{~cm}^{-1}$ is related to $\mathrm{C}=\mathrm{O}$ asymmetric stretching of aromatics which was not observed in $\mathrm{BC}_{\mathrm{Fe}-\mathrm{CH}}$. These last bands decreased or disappeared with the increase of temperature for both biochars (CH and SB) (Baig et al., 2014; Van Vinh et al., 2015). Bands around 1200 and $1000 \mathrm{~cm}^{-1}$ are typical of cellulose and hemicellulose due to the $\mathrm{C}-\mathrm{O}$ and $\mathrm{C}-\mathrm{N}$ stretching. These bands can also be associated to ashes in elevated temperatures. The bands in the region of 1700 and $1563 \mathrm{~cm}^{-1}$ for $\mathrm{BC}_{\mathrm{Fe}-\mathrm{CH}}$ indicate the presence of carbonyl groups of hemicellulose and $\mathrm{C}-\mathrm{O}$ stretching of carboxyl groups, which reveals interactions with Fe(III) ions (Baig et al., 2014; Van Vinh et al., 2015).

\subsection{Adsorption experiments}

Although the $\mathrm{pH}$ is a key factor in As(III) adsorption, a significant difference among the removal rates was not observed at the $\mathrm{pH}$ range used. The Visual MINTEQ results (Fig. A.3 to Fig. A.5, Supplementary Material) showed no As(III) precipitation in any of the experimental conditions. It supports the results of the experiments without adsorbents, where no As precipitation was observed.

The non-modified biochars $\left(\mathrm{BC}_{\mathrm{SB}}\right.$ e $\mathrm{BC}_{\mathrm{CH}}$ ) had a small adsorption efficiency (Fig. 2A). On the other hand, the $\mathrm{BC}_{\mathrm{Fe}-\mathrm{SB}}$ produced at $300{ }^{\circ} \mathrm{C}$ and all $\mathrm{BC}_{\mathrm{Fe}-\mathrm{CH}}$ adsorbed more than $90 \%$ of $\mathrm{As}(\mathrm{III})$ at all $\mathrm{pH}$ tested 

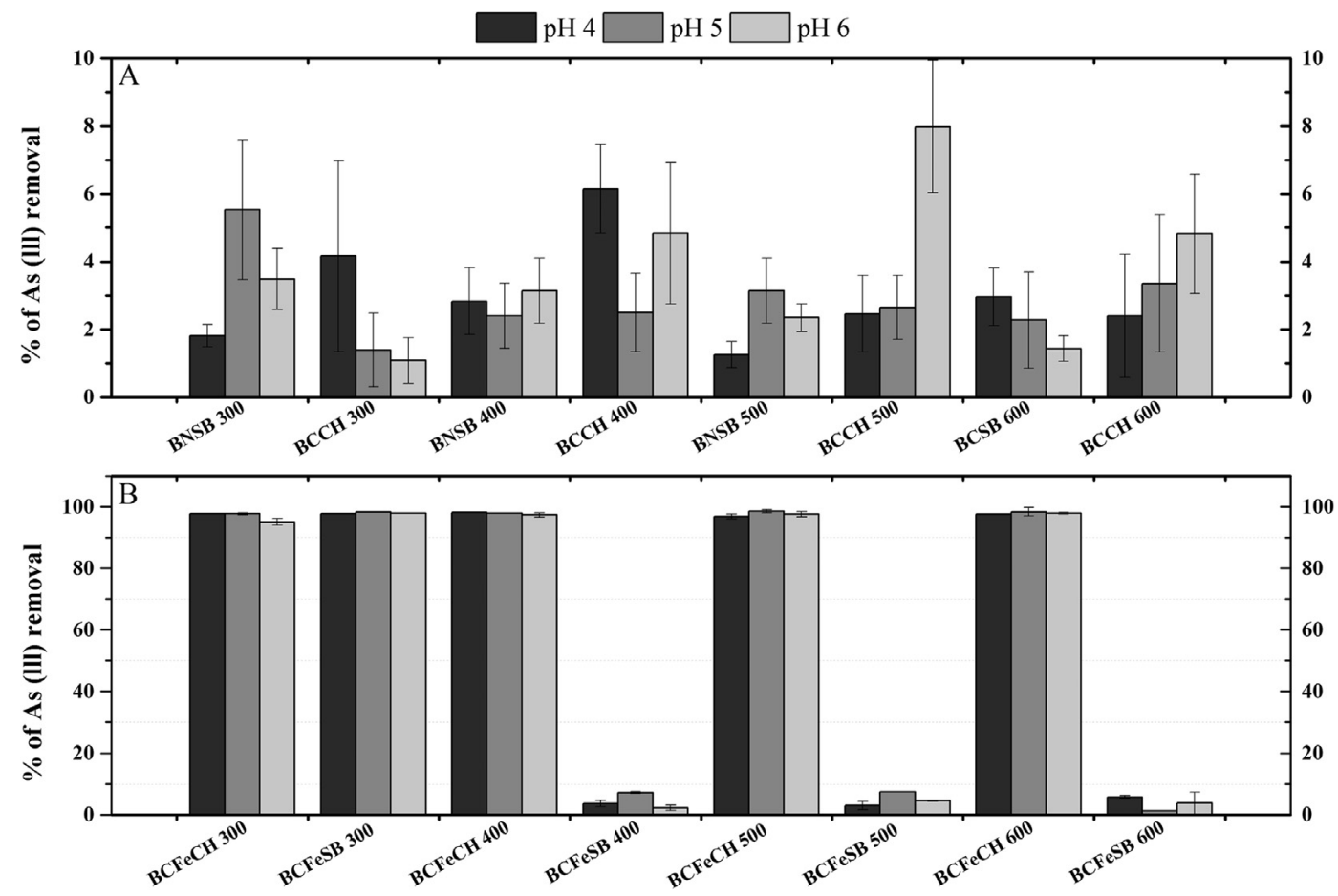

Pyrolysis temperature $\left({ }^{\circ} \mathrm{C}\right)$

Fig. 2. Removal of As(III) using biochar from corncob husk (CH) and sugarcane bagasse (SB) produced at different temperatures. A: experiments with unmodified biochar (BC); B: experiments with Fe-coated biochar $\left(\mathrm{BC}_{\mathrm{Fe}}\right)$.

(Fig. 2B). This behaviour can be explained by the higher positive charge and modification of functional groups on the biochar surface due to $\mathrm{Fe}$ (III) impregnation (Van Vinh et al., 2015; Vithanage et al., 2017).

Since the $\mathrm{pH}$ influences the As species distribution, the adsorption mechanisms will be different and more complex depending on the $\mathrm{pH}$ of the solution. The different As species and their dissociation constants are shown in Eqs. (6)-(11) (Vithanage et al., 2017; Wei et al., 2016). The higher removal rate by some biochars can be attributed to some neutral and anionic As(III) species. Although the neutral As(III) specie $\left(\mathrm{H}_{3} \mathrm{AsO}_{3}\right)$ is the most prevalent and stable in the $\mathrm{pH}$ range between 0 and 9, the specie $\mathrm{H}_{2} \mathrm{AsO}_{4}{ }^{-}$may also be present. Consequently, both species can bind to biochar (Samsuri et al., 2013; Van Vinh et al., 2015; Vithanage et al., 2017).

$$
\begin{aligned}
& \mathrm{H}_{3} \mathrm{AsO}_{3(a q)} \leftrightarrow H_{(a q)}^{+}+\mathrm{H}_{2} \mathrm{AsO}_{3(a q)}^{-} \quad p K_{1}=9.23 \\
& \mathrm{H}_{2} \mathrm{AsO}_{3(a q)}^{-} \leftrightarrow H_{(a q)}^{+}+\mathrm{HAsO}_{3(a q)}^{2-} \quad p K_{2}=12.10 \\
& \mathrm{HAsO}_{3(a q)}^{2-} \leftrightarrow H_{(a q)}^{+}+\mathrm{AsO}_{3(a q)}^{3-} \quad p K_{3}=13.41 \\
& \mathrm{H}_{3} \mathrm{AsO}_{4(a q)} \leftrightarrow H_{(a q)}^{+}+\mathrm{H}_{2} \mathrm{AsO}_{4(a q)}^{-} \quad p K_{1}=2.30 \\
& \mathrm{H}_{2} \mathrm{AsO}_{4(a q)}^{-} \leftrightarrow H_{(a q)}^{+}+\mathrm{HAsO}_{4(a q)}^{2-} \quad p K_{2}=6.8 \\
& \mathrm{HAsO}_{4(a q)}^{2-} \leftrightarrow H_{(a q)}^{+}+\mathrm{AsO}_{4(a q)}^{3-} \quad p K_{3}=11.6
\end{aligned}
$$

The higher As(III) removal efficiency observed for $\mathrm{BC}_{\mathrm{Fe}}(99.9 \%$, Fig. 2) in relation to $\mathrm{BC}(6-8 \%)$ can be attributed to the formation of new functional groups (higher $\mathrm{O}$ content, carboxylic acid-like) and elements such as $\mathrm{K}, \mathrm{Mg}$ and $\mathrm{P}$ as indicated by the EDS analysis (Fig. 1). Consequently, the increasing number of active sites on $\mathrm{BC}_{\mathrm{Fe}}$ leads to a higher As(III) adsorption on the biochar surface, especially for $\mathrm{BC}_{\mathrm{Fe}-\mathrm{CH}}$.

Another factor responsible for the higher removal efficiency of all $\mathrm{BC}_{\mathrm{Fe}}$ is the presence of more positive charges on the surface, which were already positively charged at $\mathrm{pH} 4,5$ and 6 (see Section 3.1). The introduction of $\mathrm{Fe}(\mathrm{III})$ on BC surface enhanced its capacity of immobilising As(III) through formation of surface complexes with Ocontaining functional groups or through As interactions with $\mathrm{FeOH}$ and $\mathrm{FeOH}_{2}{ }^{+}$on the biochar surface. In addition, electrostatic interactions can favour the adsorption of the species $\mathrm{H}_{3} \mathrm{AsO}_{3}$ on $\mathrm{BC}_{\mathrm{Fe}-\mathrm{SB}}$ and $\mathrm{BC}_{\mathrm{Fe}-\mathrm{CH}}$ (Samsuri et al., 2013; Vithanage et al., 2017).

The FTIR spectra comparing $\mathrm{BC}_{\mathrm{Fe}}$ and $\mathrm{As}$ (III) loaded $\mathrm{BC}_{\mathrm{Fe}}$ (Fig. A.9, Supplementary Section) were used to better investigate the binding mechanisms of the metalloid in biochar. These spectra showed a change in the size and shape of the bands around $1078 \mathrm{~cm}^{-1}$ (attributed to ester of alcohols and carboxylic acid groups (Asfaram et al., 2016)), which is probably related to ion exchange and/or electrostatic interaction, which supports our former discussions (Niazi et al., 2018a). Shifts in the positions of spectral bands were also observed for the bands around $1580 \mathrm{~cm}^{-1}$ (related to aromatic compounds), which shifts to $1530 \mathrm{~cm}^{-1}$ after As(III) adsorption. Furthermore, the band around $690 \mathrm{~cm}^{-1}$ disappears in the $\mathrm{BC}_{\mathrm{Fe}-\mathrm{SB}}$ loaded by As(III) indicating formation/breaking of chemical bonds. Particularly for the bands below $800 \mathrm{~cm}^{-1}$ these changes are related to $\mathrm{Fe}-\mathrm{O}$ bond deformations on the $\mathrm{BC}_{\mathrm{Fe}}$ surface (Kulaksiz et al., 2017).

Experiments of adsorption of the $\mathrm{BC}_{\mathrm{Fe}}$ at different ionic strengths (Fig. A.7, Supplementary Section) indicate that the amount of adsorbed As(III) decreases when ionic strength increases. It supports the effect of electrostatic attraction in the process of adsorption. Comparing the two types of tested $\mathrm{BC}_{\mathrm{Fe}}$ with one another, the influence of ionic strength was smaller for $\mathrm{BC}_{\mathrm{Fe}-\mathrm{CH}}$ than for $\mathrm{BC}_{\mathrm{Fe}-\mathrm{SB}}$. This indicates that groups present in $\mathrm{BC}_{\mathrm{Fe}-\mathrm{CH}}$ have higher affinity to $\mathrm{As}(\mathrm{III})$ and form more stable complexes. All possible interactions between $\mathrm{BC}_{\mathrm{Fe}}$ and $\mathrm{As}(\mathrm{III})$ can be described in the Eqs. (12)-(14) (Samsuri et al., 2013; Vithanage et al., 2017):

$$
\begin{aligned}
& \text { Biochar }-\mathrm{FeOH}+\mathrm{H}_{2} \mathrm{AsO}_{3} \leftrightarrow \text { Biochars }-\mathrm{FeH}_{2} \mathrm{AsO}_{3}^{-}+\mathrm{H}_{2} \mathrm{O} \\
& \text { Biochar }-\mathrm{FeOH}+\mathrm{H}_{2} \mathrm{AsO}_{3}^{-} \leftrightarrow \text { Biochars }-\mathrm{FeHAsO}_{3}^{-}+\mathrm{H}_{2} \mathrm{O} \\
& \text { Biochar }-\mathrm{FeOH}_{2}^{+}+\mathrm{H}_{2} \mathrm{AsO}_{3}^{-} \leftrightarrow \text { Biochars }-\mathrm{FeOH}_{2}-\mathrm{H}_{2} \mathrm{AsO}_{3}
\end{aligned}
$$

$\mathrm{BC}_{\mathrm{Fe}-\mathrm{CH}}$ was more efficient in the removal of As(III) since a small 
mass gets very close to the maximum adsorption when compared with $\mathrm{BC}_{\mathrm{Fe}-\mathrm{SB}}$ (see results in Appendix A, Fig. A.6). In general, as the mass increases, more active sites on biochar surface will be available. Therefore, a higher level of As(III) adsorption would be expected. Nevertheless, in this study a decrease of about $5-12 \%$ was detected in As(III) removal when the mass was increased to $0.5 \mathrm{~g}$ to both biochars $\mathrm{BC}_{\mathrm{Fe}-\mathrm{SB}}$ and $\mathrm{BC}_{\mathrm{Fe}-\mathrm{CH}}$. This behaviour can be explained by higher presence of sites of lower energy (Shukla et al., 2002).

\subsection{Contact time and adsorption kinetics}

Applying kinetic parameters (Table A.2) to the pseudo-second order model fit well to the experimental data $\left(\mathrm{r}^{2}\right.$ close to 1.00) derived from both $\mathrm{BC}_{\mathrm{Fe}-\mathrm{SB}}$ and $\mathrm{BC}_{\mathrm{Fe}-\mathrm{CH}}$. Fitting data of both Fe-coated biochars in this model indicates that the availability of binding sites on the surface of the $\mathrm{BC}_{\mathrm{Fe}}$ depends on the reaction rate (Vithanage et al., 2017). In addition, the adsorption of As species on both types of $\mathrm{BC}_{\mathrm{Fe}}$ was fast and the equilibrium time to a complete adsorption was $10 \mathrm{~min}$ and the amount of adsorbate at the equilibrium time was 0.72 and $0.96 \mu \mathrm{g} / \mathrm{g}$ to $\mathrm{BC}_{\mathrm{Fe}-\mathrm{SB}}$ and $\mathrm{BC}_{\mathrm{Fe}-\mathrm{CH}}$, respectively.

The pseudo-first order kinetic model did not fit well in the experimental data and was not considered in this study.

\subsection{Adsorption isotherms}

Since both $\mathrm{BC}_{\mathrm{Fe}-\mathrm{SB}}$ and $\mathrm{BC}_{\mathrm{Fe}-\mathrm{CH}}$ at $\mathrm{pH} 4$ produced at $300{ }^{\circ} \mathrm{C}$ presented excellent adsorption capacities, the isotherms were built in this condition. Fig. 3 presents the Langmuir and Freundlich isotherms for As (III) adsorption on the $\mathrm{BC}_{\mathrm{Fe}}$ tested as well as the experimental data. The results of the adsorption isotherms were taken from the amount of metalloid adsorbed $(\mu \mathrm{g} / \mathrm{g})$ and the concentration at equilibrium $(\mu \mathrm{g} / \mathrm{L})$. The results show that the Langmuir and Freundlich models presented values close to the ones found in the isotherms. However, Langmuir was the model that best described the As(III) adsorption process in both biochars analysed with higher $\mathrm{r}^{2}\left(0.97\right.$ and 1.00 to $\mathrm{BC}_{\mathrm{Fe}-\mathrm{SB}}$ and $\mathrm{BC}_{\mathrm{Fe}-\mathrm{CH}}$, respectively) when compared with the Freundlich model. It indicated that adsorption process took place in a monolayer of As(III) onto the surface of both $\mathrm{BC}_{\mathrm{Fe}}$, in homogeneous sites specific for biochar. This shows that the adsorption was chemical, with maximum amount of As (III) adsorbed per gram of adsorbent $\left(\mathrm{Q}^{0}\right)$ of $20 \mathrm{mg} / \mathrm{g}$ and $50 \mathrm{mg} / \mathrm{g}$ to $\mathrm{BC}_{\mathrm{Fe}-\mathrm{SB}}$ and $\mathrm{BC}_{\mathrm{Fe}-\mathrm{CH}}$, respectively.
The materials (SB and $\mathrm{CH}$ ) used for producing the biochar had good sorption capacity when compared to other materials already studied in the literature. Table 1 compares the best sorption model and maximum sorption capacities for other materials and the type of As used in the tests.

\subsection{Desorption experiments}

The amounts of desorbed $\mathrm{As}(\mathrm{III})$ were $6 \%$ and $3 \%$ for $\mathrm{BC}_{\mathrm{Fe}-\mathrm{SB}}$ and $\mathrm{BC}_{\mathrm{Fe}-\mathrm{CH}}$, respectively. The low amount of $\mathrm{As}(\mathrm{III})$ desorbed indicates a strong affinity between the metalloid and both types of $\mathrm{BC}_{\mathrm{Fe}}$, particularly with $\mathrm{BC}_{\mathrm{Fe}-\mathrm{CH}}$, which supports the results of the experiments with different ionic strengths (Section 3.2). In addition, the low desorption values indicate that the process is irreversible (do Nascimento et al., 2016).

Although the results suggested that the $\mathrm{BC}_{\mathrm{Fe}}$ cannot be reused after the first adsorption at the studied conditions, experiments of re-adsorption showed a removal of $75 \%$ and $60 \%$ of $\mathrm{As}(\mathrm{III})$ for $\mathrm{BC}_{\mathrm{Fe}-\mathrm{CH}}$ and $\mathrm{BC}_{\mathrm{Fe}-\mathrm{SB}}$ respectively. It suggests that there were still free binding sites after the first adsorption.

\subsection{Commercially activated carbon versus Fe-coated biochar}

The results of experiments of As(III) removal by activated carbon compared with $\mathrm{BC}_{\mathrm{Fe}}$ produced from $\mathrm{CH}$ and $\mathrm{SB}$ are shown in Fig. 4. The Fe-coated biochars produced from both feedstock had a higher percentage of As(III) removal when compared with commercially activated carbon.

The activated carbon can also be impregnated with Fe as biochar. However, this process would make the process of production even more expensive, which makes the use of Fe-coated biochar a good environmental and economic solution to remove As ions from natural waters and effluents (Vithanage et al., 2017).

\subsection{Column leaching experiments}

The results of trials with glass columns (Fig. 5) indicates that the commercial use of $\mathrm{BC}_{\mathrm{Fe}-\mathrm{SB}}$ and $\mathrm{BC}_{\mathrm{Fe}-\mathrm{CH}}$ for $\mathrm{As}(\mathrm{III})$ removal is practicable, since both adsorbents had good removal rates $(99 \%$ and $96 \%$ respectively). Moreover, it was demonstrated that the adsorption process is fast $\left(10 \mathrm{~min}\right.$ for $\mathrm{BC}_{\mathrm{Fe}-\mathrm{SB}}$ and $30 \mathrm{~min}$ for $\left.\mathrm{BC}_{\mathrm{Fe}-\mathrm{CH}}\right)$ and the contact time
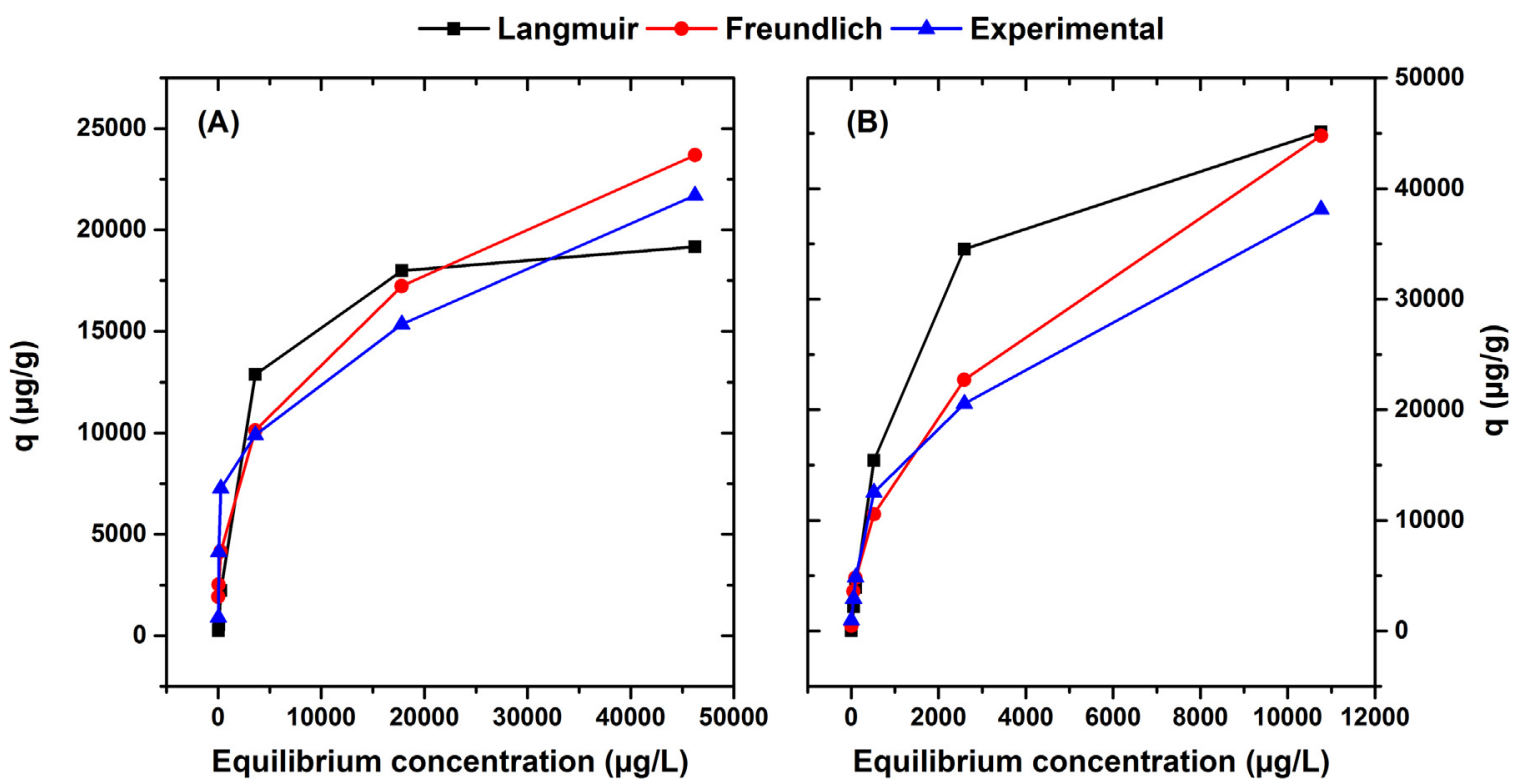

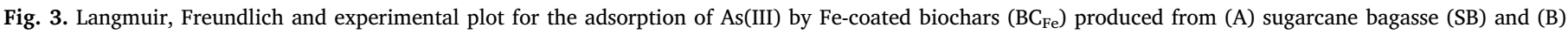
corncob husk $(\mathrm{CH})$. Both SB and $\mathrm{CH}$ biochars were produced at $300{ }^{\circ} \mathrm{C}$. 


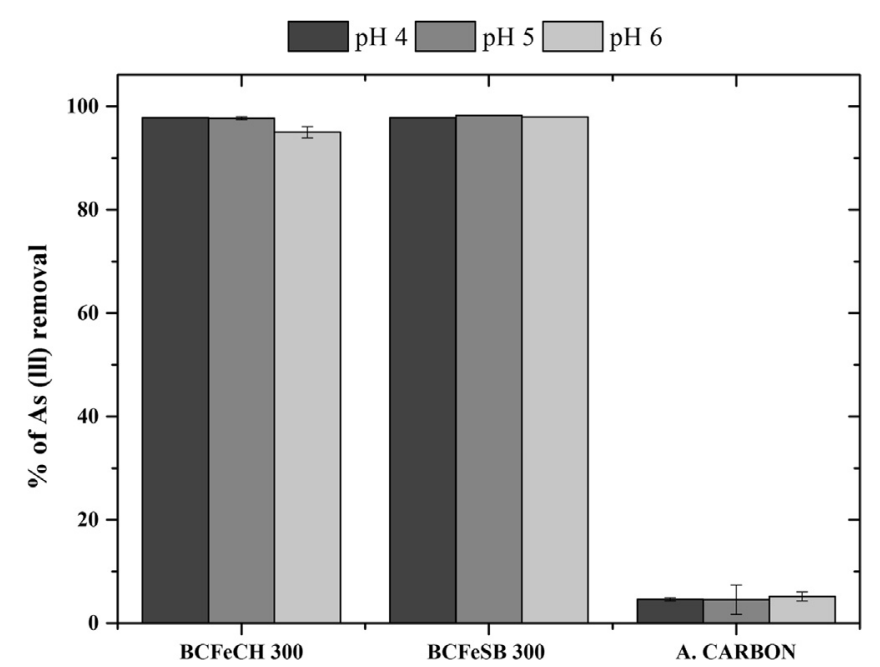

Fig. 4. Comparing As(III) adsorption on commercially activated carbon and Fecoated $\left(\mathrm{BC}_{\mathrm{Fe}}\right.$ ) biochars produced from sugarcane bagasse $(\mathrm{SB})$ and corncob husk $(\mathrm{CH})$. All $\mathrm{BC}_{\mathrm{Fe}}$ produced at $300^{\circ} \mathrm{C}$ and the experiments performed at $\mathrm{pH} 4$.

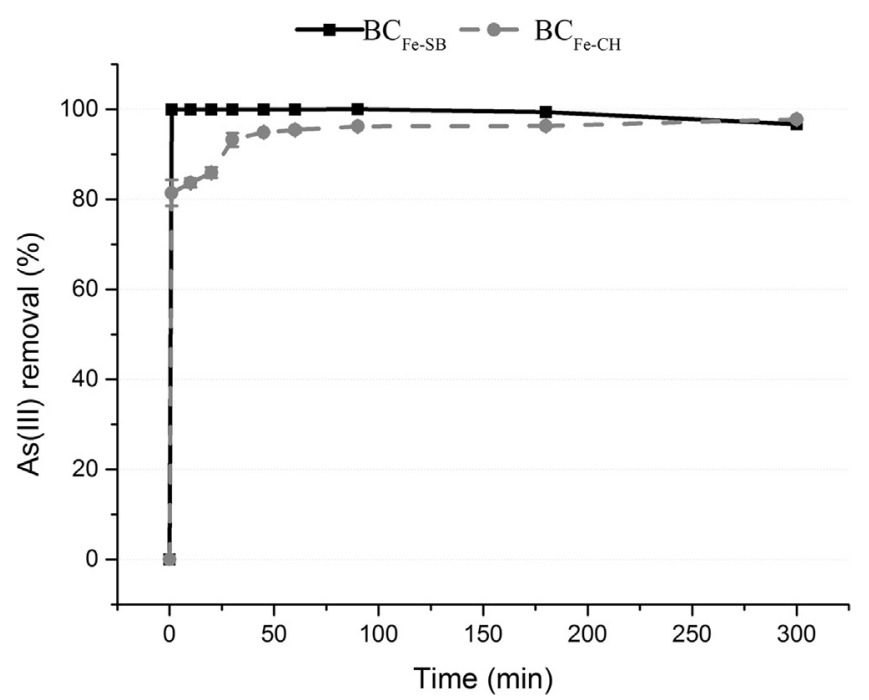

Fig. 5. Column leaching experiments results. The columns were packed either with $\mathrm{BC}_{\mathrm{Fe}-\mathrm{SB}}$ or $\mathrm{BC}_{\mathrm{Fe}-\mathrm{CH} \text {. }}$

was enough to remove nearly all As(III) from high concentration solutions $(50 \mathrm{mg} / \mathrm{L})$. The fast kinetics is attractive for both in situ remediation and use in filters applications, since time and efficiency are required in new technologies.

\section{Conclusions}

The modification of BC produced from SB and $\mathrm{CH}$ with $\mathrm{Fe}(\mathrm{III})$ improved significantly As(III) adsorption (> 99\%). However, the $\mathrm{BC}_{\mathrm{Fe}-\mathrm{CH}}$ was highly efficient for all pyrolysis temperatures, while $\mathrm{BC}_{\mathrm{Fe}-\mathrm{SB}}$ had good removal results only when produced at $300^{\circ} \mathrm{C}$. The process of As (III) adsorption had fast kinetics (10-30 min) and it was better adjusted to pseudo-second order and Langmuir models. The maximum adsorption capacity was superior to other studies in literature $(20 \mathrm{mg} / \mathrm{g}$ for $\mathrm{BC}_{\mathrm{Fe}-\mathrm{SB}}$ and $50 \mathrm{mg} / \mathrm{g}$ for $\mathrm{BC}_{\mathrm{Fe}-\mathrm{CH}}$ ). Batch and column desorption experiments showed that the adsorption process is almost irreversible. However, tests of re-adsorption indicated that there were still binding sites available, but the removal rates were $20-30 \%$ smaller than in the first adsorption-desorption phase.

The fast removal process makes the $\mathrm{BC}_{\mathrm{Fe}-\mathrm{CH}}$ and $\mathrm{BC}_{\mathrm{Fe}-\mathrm{SB}}$ attractive for in situ and commercial (filters) use, since time and efficiency are 
required in new technologies. The use of $\mathrm{BC}$ as an adsorbent to remove As(III) is cheap, which makes its usage particularly advantageous when compared to other traditional techniques (activated carbon for instance). In addition, there are other benefits related to reuse of leftovers of biomass produced in large amounts in countries like Brazil and China. The disposal of these residues in the fields may pose risks to crops, such as fire or delay in plant development.

\section{Acknowledgements}

This study was supported by Consejo Nacional Ciência y Tecnología (CONACyT, Grant number 579774), Fundacao de Amparo a Pesquisa do Estado de Sao Paulo (FAPESP, Grant numbers 2012/17727-8; 2013/ 08373-0, 2013/24168-8 and 2016/08215-4), Coordenacao de Aperfeicoamento de Pessoal de Nível Superior (CAPES) (99999.008107/2015-07) and Conselho Nacional de Desenvolvimento Científico e Tecnológico (CNPq) (303189/2013-4). The authors acknowledge the help of Prof. Dr. Elidiane Cipriano Rangel (Group of Plasmas and Materials, Institute of Science and Technology, Sao Paulo State University - UNESP) for the SEM-EDS analyses and Prof. Dr. Daniel Komatsu (Pontifical Catholic University, PUC) for the help with FTIR analysis.

\section{Appendix A. Supplementary material}

Supplementary data associated with this article can be found in the online version at doi:10.1016/j.ecoenv.2018.07.042.

\section{References}

Agrafioti, E., et al., 2014. Arsenic and chromium removal from water using biochars derived from rice husk, organic solid wastes and sewage sludge. J. Environ. Manag. 133, 309-314.

Ahn, J.S., et al., 2003. Arsenic removal using steel manufacturing byproducts as permeable reactive materials in mine tailing containment systems. Water Res. 37, $2478-2488$.

Asfaram, A., et al., 2017a. Ultrasound-assisted binary adsorption of dyes onto Mn@ CuS/ ZnS-NC-AC as a novel adsorbent: application of chemometrics for optimization and modeling. J. Ind. Eng. Chem. 54, 377-388.

Asfaram, A., et al., 2018. Preparation and characterization of Mn0.4Zn0.6Fe2O4 nanoparticles supported on dead cells of yarrowia lipolytica as a novel and efficient adsorbent/biosorbent composite for the removal of azo food dyes: central composite design optimization study. ACS Sustain. Chem. Eng. 6, 4549-4563.

Asfaram, A., et al., 2016. Biosorption of $\mathrm{Zn} 2+$, Ni2 + and $\mathrm{Co} 2+$ from water samples onto Yarrowia lipolytica ISF7 using a response surface methodology, and analyzed by inductively coupled plasma optical emission spectrometry (ICP-OES). RSC Adv. 6, 23599-23610.

Asfaram, A., et al., 2017b. Application of experimental design and derivative spectrophotometry methods in optimization and analysis of biosorption of binary mixtures of basic dyes from aqueous solutions. Ecotoxicol. Environ. Saf. 139, 219-227.

Asfaram, A., et al., 2015. Response surface methodology approach for optimization of simultaneous dye and metal ion ultrasound-assisted adsorption onto Mn doped Fe3O4-NPs loaded on AC: kinetic and isothermal studies. Dalton Trans. 44, $14707-14723$.

Azizur Rahman, M., Hasegawa, H., 2012. Arsenic in freshwater systems: influence of eutrophication on occurrence, distribution, speciation, and bioaccumulation. Appl. Geochem. 27, 304-314.

Baig, S.A., et al., 2014. Effect of synthesis methods on magnetic Kans grass biochar for enhanced As(III, V) adsorption from aqueous solutions. Biomass Bioenergy 71, 299-310.

Ballinas, M. d.L., et al., 2004. Arsenic(V) removal with polymer inclusion membranes from sulfuric acid media using DBBP as carrier. Environ. Sci. Technol. 38, 886-891.

Bazrafshan, A.A., et al., 2017. Synthesis of ZnO-nanorod-based materials for antibacterial, antifungal activities, DNA cleavage and efficient ultrasound-assisted dyes adsorption. Ecotoxicol. Environ. Saf. 142, 330-337.

Budinova, T., et al., 2006. Removal of arsenic(III) from aqueous solution by activated carbons prepared from solvent extracted olive pulp and olive stones. Ind. Eng. Chem. Res. 45, 1896-1901.

Bueno, C.C., et al., 2017. Investigation on prospective energy power from corncob husk biomass and its biochars by kinetic parameters and isoconversional models. J. Braz. Chem. Soc.

Chandra, V., et al., 2010. Water-dispersible magnetite-reduced graphene oxide composites for arsenic removal. ACS Nano. 4, 3979-3986.

Choong, T.S.Y., et al., 2007. Arsenic toxicity, health hazards and removal techniques from water: an overview. Desalination 217, 139-166.

Corapcioglu, M.O., Huang, C.P., 1987. The surface acidity and characterization of some commercial activated carbons. Carbon 25, 569-578.

Cumbal, L., et al., 2003. Polymer supported inorganic nanoparticles: characterization and environmental applications. React. Funct. Polym. 54, 167-180.

Dambies, L., 2005. Existing and prospective sorption technologies for the removal of arsenic in water. Sep. Sci. Technol. 39, 603-627.

Diamadopoulos, E., et al., 1993. As(V) removal from aqueous solutions by fly ash. Water Res. 27, 1773-1777.

do Nascimento, F.H., et al., 2016. Evaluation of thiol-modified vermiculite for removal of $\mathrm{Hg}$ (II) from aqueous solutions. Appl. Clay Sci. 124-125, 227-235.

Domingues, M.T., et al., 2014. Polymeric alginate microspheres containing biochar to immobilize phosphate ions. Chem. Eng. Trans. 37, 109-114.

Dong, C.-D., et al., 2018. Wood-biochar-supported magnetite nanoparticles for remediation of PAH-contaminated estuary sediment. Catalysts 8, 73 .

Genç, H., et al., 2003. Adsorption of arsenate from water using neutralized red mud. J. Colloid Interface Sci. 264, 327-334.

Ghimire, K.N., et al., 2002. Effectiveness of phosphorylated orange residue for toxic oxoanion removal. Des. Monomers Polym. 5, 401-414.

Gihring, T.M., et al., 2001. Rapid arsenite oxidation by thermus aquaticus and thermus thermophilus: field and laboratory investigations. Environ. Sci. Technol. 35, 3857-3862.

Guo, X., Chen, F., 2005. Removal of arsenic by bead cellulose loaded with iron oxyhydroxide from groundwater. Environ. Sci. Technol. 39, 6808-6818.

Gupta, V.K., et al., 2005. Adsorption of As(III) from aqueous solutions by iron oxidecoated sand. J. Colloid Interface Sci. 288, 55-60.

Haron, M.J., Yunus, M.Z.W., Sukari, M.A., Wum, L.T., Tokugana, S., 1997. Removal of arsenic(V) by cerium(III) complexed chelating ion exchanger. The Malaysian. J. Anal Sci. 3, 193-204.

Hering, J.G.C., Pen-Yuan, Wilkie, Jennifer A., Elimelech, Menachem, Liang, Sun, 1996. Arsenic removal by ferric chloride. J. Am. Water Works Assoc. 88, 155-167.

Ho, Y.S., McKay, G., 1999. Pseudo-second order model for sorption processes. Process Biochem. 34, 451-465.

Huang, W., et al., 1998. Hysteresis in the sorption and desorption of hydrophobic organic contaminants by soils and sediments: 1 . A comparative analysis of experimental protocols. J. Contam. Hydrol. 31, 129-148.

Jain, C.K., Ali, I., 2000. Arsenic: occurrence, toxicity and speciation techniques. Water Res. 34, 4304-4312.

Kim, D.H., et al., 2006a. Removal and transport mechanisms of arsenics in UF and NF membrane processes. J. Water Health 4, 215-223.

Kim, J., et al., 2006b. Arsenic removal from water using lignocellulose adsorption medium (LAM). J. Environ. Sci. Health A Tox Hazard Subst. Environ. Eng. 41, 1529-1542.

Kordmostafapour, F., et al., 2006. Arsenic removal by dissolved air flotation. J. Appl. Sci. 6, 1153-1158.

Kulaksiz, E., et al., 2017. Adsorption of Malachite Green on Fe-modified biochar: influencing factors and process optimization. Desalin. Water Treat. 74, 383-394.

Lata, S., Samadder, S.R., 2016. Removal of arsenic from water using nano adsorbents and challenges: a review. J. Environ. Manag. 166, 387-406.

Leão, G.A., et al., 2017. Phytoremediation of arsenic-contaminated water: the role of antioxidant metabolism of Azolla caroliniana Willd. (Salviniales). Acta Bot. Bras. 31, $161-168$.

Manochio, C., et al., 2017. Ethanol from biomass: a comparative overview. Renew. Sustain. Energy Rev. 80, 743-755.

Mayo, J.T., et al., 2007. The effect of nanocrystalline magnetite size on arsenic removal. Sci. Technol. Adv. Mater. 8, 71-75.

Mohan, D., Chander, S., 2006. Removal and recovery of metal ions from acid mine drainage using lignite-a low cost sorbent. J. Hazard. Mater. 137, 1545-1553.

Mohan, D., et al., 2014. Cadmium and lead remediation using magnetic oak wood and oak bark fast pyrolysis bio-chars. Chem. Eng. J. 236, 513-528.

Mohan, D., et al., 2007. Sorption of arsenic, cadmium, and lead by chars produced from fast pyrolysis of wood and bark during bio-oil production. J. Colloid Interface Sci. 310, 57-73.

Moraes, M.S.A., et al., 2012. Analysis of products from pyrolysis of Brazilian sugar cane straw. Fuel Process. Technol. 101, 35-43.

Morin, G., Calas, G., 2006. Arsenic in soils, mine tailings, and former industrial sites. Elements 2, 97-101.

Muñoz, J.A., et al., 2002. Arsenic adsorption by Fe(III)-loaded open-celled cellulose sponge. Thermodynamic and selectivity aspects. Environ. Sci. Technol. 36, 3405-3411.

Natarajan, S., et al., 2011. Phytoremediation of arsenic-contaminated groundwater using arsenic hyperaccumulator Pteris vittata L.: effects of frond harvesting regimes and arsenic levels in refill water. J. Hazard Mater. 185, 983-989.

Niazi, N.K., et al., 2018a. Arsenic removal by perilla leaf biochar in aqueous solutions and groundwater: an integrated spectroscopic and microscopic examination. Environ. Pollut. 232, 31-41

Niazi, N.K., et al., 2018b. Arsenic removal by Japanese oak wood biochar in aqueous solutions and well water: investigating arsenic fate using integrated spectroscopic and microscopic techniques. Sci. Total Environ. 621, 1642-1651.

Nidheesh, P.V., Singh, T.S.A., 2017. Arsenic removal by electrocoagulation process: recent trends and removal mechanism. Chemosphere 181, 418-432.

Pacheco, A.C.C., Torem, M.L., 2002. Influence of ionic strength on the removal of As(V) by adsorption colloid flotation. Sep. Sci. Technol. 37, 3599-3610.

Pokhrel, D., Viraraghavan, T., 2006. Arsenic removal from an aqueous solution by a modified fungal biomass. Water Res. 40, 549-552.

Pollard, S.J.T., et al., 1992. Low-cost adsorbents for waste and wastewater treatment: a review. Sci. Total Environ. 116, 31-52.

Qu, X., et al., 2013. Applications of nanotechnology in water and wastewater treatment. 
Water Res. 47, 3931-3946.

Ramakrishna, D.M., Viraraghavan, T., Jin, Y.-C., 2006. Coated sand for arsenic removal: investigation of coating parameters using factorial design approach. Periodical of Hazardous, Toxic, and Radioactive. Waste Manag. 10, 198-206.

Ratna Kumar, P., et al., 2004. Removal of arsenic from water by electrocoagulation. Chemosphere 55, 1245-1252.

Samsuri, A.W., et al., 2013. Adsorption of As(III) and As(V) by Fe coated biochars and biochars produced from empty fruit bunch and rice husk. J. Environ. Chem. Eng. 1 981-988.

Sharma, V.K., Sohn, M., 2009. Aquatic arsenic: toxicity, speciation, transformations, and remediation. Environ. Int. 35, 743-759.

Shukla, A., et al., 2002. The role of sawdust in the removal of unwanted materials from water. J. Hazard. Mater. 95, 137-152.

Smedley, P.L., Kinniburgh, D.G., 2002. A review of the source, behaviour and distribution of arsenic in natural waters. Appl. Geochem. 17, 517-568.

Soner Altundoğan, H., et al., 2000. Arsenic removal from aqueous solutions by adsorption on red mud. Waste Manag. 20, 761-767.

Thakur, L.S., Mondal, P., 2017. Simultaneous arsenic and fluoride removal from synthetic and real groundwater by electrocoagulation process: parametric and cost evaluation. J. Environ. Manag. 190, 102-112.

Ungureanu, G., et al., 2015. Arsenic and antimony in water and wastewater: overview of removal techniques with special reference to latest advances in adsorption. J Environ. Manag. 151, 326-342.

Van Vinh, N., et al., 2015. Arsenic(III) removal from aqueous solution by raw and zincloaded pine cone biochar: equilibrium, kinetics, and thermodynamics studies. Int. J. Environ. Sci. Technol. 12, 1283-1294.

Vithanage, M., et al., 2017. Interaction of arsenic with biochar in soil and water: a critical review. Carbon 113, 219-230.

Wang, S., et al., 2015. Removal of arsenic by magnetic biochar prepared from pinewood and natural hematite. Bioresour. Technol. 175, 391-395.

Wang, S., Mulligan, C.N., 2006. Natural attenuation processes for remediation of arsenic contaminated soils and groundwater. J. Hazard. Mater. 138, 459-470.

Wang, S., Peng, Y., 2010. Natural zeolites as effective adsorbents in water and wastewater treatment. Chem. Eng. J. 156, 11-24.

Wei, Z., et al., 2016. The effect of $\mathrm{pH}$ on the adsorption of arsenic(III) and arsenic(V) at the TiO2 anatase [101] surface. J. Colloid Interface Sci. 462, 252-259.

Zhang, F.-S., Itoh, H., 2005. Iron oxide-loaded slag for arsenic removal from aqueous system. Chemosphere 60, 319-325.

Zhang, H., et al., 2010. Effect of Pinus radiata derived biochars on soil sorption and desorption of phenanthrene. Environ. Pollut. 158, 2821-2825.

Zhang, M., et al., 2013. Preparation and characterization of a novel magnetic biochar for arsenic removal. Bioresour. Technol. 130, 457-462. 